\title{
Foreword
}

\section{Aminu Mamman}

In the last three decades, the topic of management ideas has been receiving the attention of scholars and researchers. Although management innovation has been in practice since the Industrial Revolution, not until the era of scientific management and human relation schools did scholars and researchers start to treat the subject with the seriousness it deserves. Similarly, the topic of innovation has been studied since the seminal work on entrepreneurship as creative destruction by Schumpeter (1949) and Rogers' $(1971,1983$, 1995) influential texts on adoption and diffusion of innovation, but it can be argued that up until the mid-1970s (for example, Baldridge and Burnham 1975), there has been no significant effort to study and research management ideas as a distinct field of research. Instead, much of the research and commentaries on management ideas have largely focused on the critique of the validity and/or efficacy of specific management ideas such as total quality management, business process reengineering and a host of other management ideas/panaceas. As a result, management ideas/panaceas as a body of knowledge did not take hold in mainstream management literature until the pioneering works of researchers on the topic, such as Abrahamson (1991, 1996), Abrahamson and Rosenkopf (1993), Damanpour (1987, 1988, 1991), Damanpour and Evan (1984), Downs and Mohr (1976), Hage and Dewar (1973) and Kimberly and Evanisko (1981). The emergence of management innovation and ideas as a body of knowledge and field of research has undoubtedly increased the perception of management as a credible discipline that can make an impact on how organizations and business enterprises can achieve their objectives through the adoption of Management Innovation. However, given that management ideas cannot be panaceas (cure-alls) to those who adopt them, identifying the condition under which such ideas would work should be one of the most important areas of research. Therefore, the significance of a book that attempts to critique and contextualize management ideas cannot be overemphasized. The collection of chapters in this book has provided the needed impetus required to keep alive the debate on the relevance and efficacy of management ideas.

While advocacy for the development of new ideas in management should continue and management gurus that propound such ideas be commended, researchers must forge forward in testing and critiquing 
the validity and efficacy of such ideas. This is because it is only through research that the credibility of the ideas and management discipline in general can be maintained. Professor Anders Örtenblad's effort to assemble a collection of experts to critique, comment and advocate research on management ideas and panaceas is a significant contribution towards this direction and commendable. The four parts of the book have systematically covered key issues coherently put together to ensure that the reader makes sense of the relevance of management ideas in the contemporary era of turbulence and change which ignited the propounding, adoption and diffusion of management ideas since the beginning of the 20th century. The book is rightly conceived as a collection of chapters not aimed at critiquing management ideas, but rather as articulations of perspectives through which to shed light on areas and issues that can guide researchers and practitioners. An alluring aspect of the book is the emphasis on the need to contextualize management ideas. To this end, the book identifies researchers, practitioners, educators and students, through which the contextualization of management ideas/panaceas will be achieved. The critique, practical suggestions and direction for research provided in the final part of the book have undoubtedly made the book more engaging. All-embracing books of this kind are rare in management because most books either target the practitioner or the scholar/researcher. This book ensures that the practitioner understands and benefits from the theoretical basis of management ideas and the need to contextualize the idea after adoption. Similarly, the researcher should benefit from the array of perspectives and critiques presented. Perhaps most importantly, the researchers will have at the back of their mind that the most important question in any theory or research in management is whether it offers a solution to problems faced by practitioners. Therefore, it is apt that the book adopted an instrumental perspective to the topic of management ideas/panaceas. The book is undoubtedly an invitation to researchers, practitioners and educators/students who are embarking on or who wish to embark on a journey towards understanding the practical and theoretical complexity of management ideas/panaceas. The book is a welcome addition to the body of knowledge that is emerging pertaining to management innovation and the challenge of making research relevant to practitioners. In my opinion, this book should be amongst the collection of management books in all the libraries of business schools for the benefit of scholars, researchers, teachers and their students. Well done Professor Örtenblad.

Aminu Mamman

Reader at the University of Manchester 


\section{REFERENCES}

Abrahamson, E. (1991), 'Managerial fads and fashions: the diffusion and rejection of innovations', Academy of Management Review, 16 (3), 586-612.

Abrahamson, E. (1996), 'Management fashion', Academy of Management Review, 21 (1), 254-85.

Abrahamson, E. and L. Rosenkopf (1993), 'Institutional and competitive bandwagons: using mathematical modelling as a tool to explore innovation diffusion', Academy of Management Review, 18 (3), 487-517.

Baldridge, J.V. and R.A. Burnham (1975), 'Organizational innovation: individual organizational and environmental impacts', Administrative Science Quarterly, 20 (2), 165-76.

Damanpour, F. (1987), 'The adoption of technological, administrative, and ancillary innovations: impact of organizational factors', Journal of Management, 13 (4), 675-88.

Damanpour, F. (1988), 'Innovation type, radicalness, and the adoption process', Communication Research, 15 (5), 545-67.

Damanpour, F. (1991), 'Organizational innovation: a meta-analysis of effects of determinants and moderators', Academy of Management Journal, 34 (3), 555-9.

Damanpour, F. and W.M. Evan (1984), 'Organizational innovation and performance: the problem of "organizational lag"”, Administrative Science Quarterly, 29 (3), 392-409.

Downs, G.W. and L.B. Mohr (1976), 'Conceptual issues in the study of innovations', Administrative Science Quarterly, 21 (4), 700-714.

Hage, J. and R. Dewar (1973), 'Elite values versus organizational structure in predicting innovation', Administrative Science Quarterly, 18 (3), 279-90.

Kimberly, J.R. and M.J. Evanisko (1981), 'Organizational innovation: the influence of individual, organizational and contextual factors on hospital adoption of technological and administrative innovations', Academy of Management Journal, 24 (4), 689-713.

Rogers, Everett M. (1971), Communication of Innovation, New York: The Free Press.

Rogers, Everett M. (1983), Diffusion of Innovations, New York: The Free Press.

Rogers, Everett M. (1995), Diffusion of Innovations, New York: The Free Press.

Schumpeter, Joseph A. (1949), Theory of Economic Development, Cambridge, MA: Harvard University Press. 